\title{
CORRUPTION IN SERBIA AND IN SURROUNDINGS
}

\section{Jelena Ivanovic}

Faculty of Business and Industrial Management of the "UNION - Nikola

Tesla“ University in Belgrade, Belgrade, Serbia

Marko Teslic

JKP Informatika, Novi Sad, Serbia

OMESTE

JEL Category: D73

\begin{abstract}
Corruption is connected to society since its beginnings, and struggle against it can be seen not only through moral categories but also through positive legislative regulations. Corruptions as a term and its constitutive elements have not yet been defined precisely in the Republic of Serbia. The definition used in the RS is the one given by Law on fight against corruption. The term "corruption" in broader legal sense, relates to all the forms of abuse of power and social positions done out of greed (bribery, abuse of official and social position, giving and using privileges, counerfavours, taking provisions and presents), and in narrower sense giving and taking bribery. In any case, giving and taking bribery dominates all the criminal acts of corruption. Bribery is permanently present in our citizens' consciousness as they think that corruption is mostly present in health care, Judicial system, and police force, while "politicians and political parties stand apart of all the categories". Comparative practice in the world understands corruption as abuse of power for private gain. This concept is used in Global programme of the United Nations against corruption and is accepted in European Union practice. How broad this problem is in Serbia one can see from the fact that Serbia was in the $80^{\text {th }}$ place out of 176 countries in 2012.
\end{abstract}

Keywords: politics, National Strategy, Agency for fighting against corruption, criminal Law, corruption, bribery, moral, nepotism, cronyism, conflict of interest, public functions.

\section{INTRODUCTION}

If we mark criminal offences based on corruption as a tip of the ice-berg, than it is understandable that versatile and efficient struggle against

The address of the corresponding author: Jelena Ivanović

奉= jekybratz@gmail.com corruption requires adequate legal regulative, and much more than that - moral judgment of the whole society we live in. As a matter of fact, morality decrease is a social phenomenon controlled by a number of social norms based on which people form their judgment and behaviour in relationships with others in social community, or social group they belong to. 
Moral appeared in primitive community, in before state collectives. We can state with certainty that moral is a category older than rights because there were periods of human society development where human relationships were ordered by moral, not by law, as there were no positive rights, so the relationships in these periods cannot be seen from the point of view of both morality and law.

In any case, giving and taking bribery is among criminal acts based on corruption. That is the case in Serbia, where according to available data, in December, last year citizens used to give $168 €$ in an average, which is more than in June 2012. Bribery is permanently present in our citizens' consciousness as they think that corruption is mostly present in health care, Judicial system, and police force, while "politicians and political parties stand apart of all the categories". Actually, Serbia regressed according to annual list of Transparency International and is now at $86^{\text {th }}$ place, with corruption perception index (CPI) 3,3. During 2010, Serbia was positioned between 78 . and 84. place with China, Greece, Columbia, Lesotho, Peru and Thailand, while in 2009, with the same index it was in the $83^{\text {rd }}$ place. Research presented in Media Center showed that $41 \%$ of the questioned people consider that corruption level will decrease by 2013 , and that public support to the Government of Serbia concerning struggle against corruption increased considerably. (Ivanović, 2013)

\section{APPEARING AND PREVENTING OF CORRUPTION THROUGH CENTURIES}

In the Matica Srpska dictionary, bribe is money or some other thing of value as a gift, reward that is used to make somebody satisfy the givers wish (in a dishonest, unlawful way). The older word is "diškrecija" which refers to bribe, bribery. (Vujanic \& at al, 2011) Corruption is connected to human kind ever since it has appeared, struggle against it is obvious through centuries, not only through positive regulative but also through moral categories. The Bible says "You shall not take a bribe, for a bribe blinds the clear-sighted and subverts the cause of the just." (Bible, 1963)

During the first centuries of Roman state, magistrates and other officials had an obligation to answer for any irregularity that might have appeared, within a year after their office had been finished. Numerous problems connected to corruption appeared during the last years of the Republic, when the Roman Empire grew. A procedure named questionis (court enquiry) was an attempt to prevent such cases. The procedure was performed for large offences connected to political disputes pecium repetundae - receiving bribery for the account of a province or for purposes to prevent nominating for magistrate election - election offences. Marking criminal offences as "taking presents" and extortion (crimen repetundarum) had an aim to prevent massive bribery, extortion and other abuse which could have appeared in that period while in office. By Lax Servilia a performer of an offence not only had to compensate the damages but also lost his political rights. In Raka, Syria, a Dutch team of archeologists found 150 tiles with text in cuneiform writing in 1997, which show that Raka was an administrative centre of Assyrian civilization from XIII ct. BC. They also found an archive with data on the officials receiving bribery, including names of high officials and Assyrian princess. (Koprivica, 2013)

In early feudalism, by the end of the fifth ct. Salina Law was made, stating regulations on power and position abuse and it lists abuses being made by counts. Burgundy and Ostrogot Legal Codes appear, they all mention different offences one of which is bribing judges. They all predict death penalty. In 1716, a special court was established in France whose jurisdiction was to process all the abuses connected to King's finances. However, in 1717, as embezzlements, extortions, overcharging and other forms of cheating were so common they gained a status of custom, the special court was abolished.

With appearing capitalism in France, these criminal acts were placed in new criminal Legal Codes of Europe. "Crimes of Public Officials while in office" and "Criminal Legal Code" were established in France in 1810. This period in development of France was stained by immense abuse by officials which was enabled by The Constitution and Legal Code as courts were forbidden to prosecute officials. By the Constitution of 1870 , administrative guarantee for the officials was abolished. German Criminal Law 
from 1871 stands out. The reason for this Law coming into life was to make punishments exceptionally strict as the abuses of the officials were omnipresent.

In the 18th ct. England, the term "corruption" meant bribery and corrupting government. Francis Bacon gave his personal contribution to understanding corruption. After coming to the highest legal position in England - he became lord canceller, and was caught receiving bribery for 28 times. He defended himself with words: "I usually take bribe from both sides, so dirty money cannot influence my decisions." The Parliament didn't accept his reasons so he was relieved of duty and sent to prison, where he stayed for only a couple of days as he succeeded in bribing the judge.

First written reports on criminal acts of government officials in Serbia we can trace as late as Nemanjić State, which means from XIII ct. Sava's Nomokanon from 1219 belongs to these Legal Codes. At the very end of the early period of Serbian State we can find Dušan's Legal Code (Dušan, 1349) where in the Article 110 states: "On Judges: Judges wherever they go on the lands of the Tsar and his field, that is not authorized to take meals with force, or what any other than gifts, which one gifts of his will".

During the first Serbian Rebellion there was Karađorđe's Criminal Legal Code containing 38 articles, among which we can find regulations on abuse of official position and taking bribery. Article 32 forbade the elders, captains or couplers to let the soldier go home for received bribe. The punishment was giving the money back and dishonourable discharge from the army.

In 1829 Duke Milos gave guidelines, in fact decrees, on political power in Serbia. By Act 12, it is forbidden to receive bribe or fleecing somebody.

First Criminal Code for the Kingdom of Yugoslavia was Criminal Law from 1929. Not long after it was brought the Law on abuse of official power was brought. Criminal Law makes distinction between two types of receiving bribery: 1. passive bribery in broader sense or simple bribery and 2. passive bribery or hard bribery. The law also contains regulations on bribing judges. Criminal Law from 1955, in section XXIV, under the title "Criminal Act against official duty" together with other criminal act was marked as abuse in line of duty, and Article 325 stated the act of receiving bribery.

Criminal Code of 2005 of the Republic of Serbia was renewed in 2012, apart from giving and receiving bribery and abuse of power, mostly for purposes of more effective struggle against corruption, and it contains a special chapter XXII, named "Special criminal acts of corruption" and contains eleven articles. Those acts are: giving and receiving bribery in internal relationships, foreign affairs personnel bribery, trading influence, criminal acts of corruption connected to international or supranational institutions, criminal acts of material gain (money laundry) and other criminal acts connected to corruption.

\section{CONTENTS AND EFFECTS OF CORRUPTION}

Etymologically, the word "corruption" (lat. corruption) in general sense it means neglect and abuse of power for personal gain and bribing official personal. In broader legal sense it marks all the forms of official power abuse for greed, (bribery, power abuse and authorizations, giving and using privileges, counterfavours, provisions and receiving gifts), more specifically it is an act of giving and receiving bribery. (Boskovic, 1999, p. 145) Receiving bribery (passive bribing) is aimed against proper, conscienscious, legal act of officials so by committing it one endangers a service and thus aims and tasks that service regularly fulfills. (Milosevic, 2012) Modern definitions of corruption can be classified as Administrative definitions of corruption corruption is a deviant behaviour of an individual in comparison to forma role; Economic definition corruption is maximization of profit by breaking Law and morality; Public interest definitions corruption is using public resources for personal gains. The definition of corruption was also given by World Bank: Abuse of public resources for personal gains; followed by Vito Tanci: Disturbing the principle of impartiality; and Nye and Khan: Deviant behaviour compared to formal role. (Tanci, n.d.)

Appearing corruption in a society or an institution is enforced by a monopoly in decision making and unlimited discretion rights without personal - legal 
and moral - responsibility. This leads us to a famous Klitgaard formula (Klitgaard, 2008):

$C=M+D-A$

$C$ - corruption appears when there is a monopoly of power $\mathrm{M}$ and discretion $\mathrm{D}$, and there is no responsibility $A$.

Development programme of the UN (UNDP) modified the formula adding two more dimensions - transparency (T) and integrity (I) (Selosa, 2010): $C=(M+D)-(A+T+I)$.

Corruption has been considered as an evil ever since the antic period, which influences public rule and political functioning, and today it ruins the basis of free enterprenuring eliminates rules of healthy competition important for economic development, weakens influence of democratic institutions and generally of legal state. The great minds of the past connected corruption with moral values going bad, considered it immoral and corrupting phenomenon of society and pointed out that bearers of official functions must fight for common, not for personal causes. There is a fomous Latin proverb actual even today: "corruptissimus republica plurimae leges" - most crooked state has the greatest number of Laws.

Criminal act of corruption can only be performed with intention. Intention should contain consciousness of the performer on all the circumstances of the deed, as well as a will to commit the deed, while the consciousness on the deed includes consciousness on breaking Law, consciousness of achieving personal or somebody else's gain, or bringing harm to somebody, while consciousness of possible consequences is a basic motive for committing such an act that brings to corruption. In times we live in, when basic values lose their sense, consciousness on damages or consequences that can appear while committing criminal offence of corruption, is less and less present in our society. Accepting the idea that things will get easier if somebody is bribed, leads to changing existing traditional norms.

The word corruption itself often loses its original meaning, becomes euphemism for bribery and has completely different, considerably narrower meaning than it had originally. Considering such a state, seeing certain forms of criminality that didn't exist before, and discovering all the forms of corruption and criminal behaviour and their connection to legal authorities is one of the steps of facing corruption.

The other step in consequent contact of the two already mentioned groups of social rules, law and morality. This coexistence between these two terms must exist so as to order human behaviour in a humane and decent way, or we will again come to a situation to confirm that money has the role of value measurement and that it is connected to every segment of our lives. Society itself is inclined to that idea. Criminal law theory must be extremely alive for that reason and must predict movements in this domain of positive law. Each conformism and indecisiveness in fighting corruption provokes difficult consequences society and an individual as a part of it. (Ivanovic, 2013)

\section{BASIC CLASSIFICATION AND DEFINING CORRUPTION}

Besides general understanding that bribery and corruption mean the same, there are a few types of corruption and borderline appearances. They are:

- White corruption - giving privileges based on cousin and friendship relationships, without expecting counterfavours. Example: a relative with a job in a hospital takes us to a doctor without waiting for our turn. White corruption cases are not criminal offences but could be seen as disciplinary responsibility which should be sanctioned by the employer. Gray corruption - giving privileges on "favour for favour principle". Example: There is a man in the police force that hides your traffic offence denunciation and then one day mentions that his daughter has a bad mark in mathematics that your mother teaches. Black corruption giving privileges with direct financial award. Example: a patient is waiting for a surgery and cannot wait for his turn for a "good doctor". A friend, working in the hospital offers to give the doctor a certain amount of money so the doctor would operate before his turn.

- Nepotism is a special kind of interest conflict. The term itself has a broader usage, its meaning is connected to a situation where somebody uses his power to gain advantage 
for his family member (for example an uncle uses his position to employ a nephew). Cronyism is a broader term than nepotism and is used for situations when advantage is given to friends and colleges. For example, in the UK, cronyism means "old school relationships" or "boys from the old club". Conflict of interest is a situation when, for purposes of material gain, a public official puts private in front of public interest. These are situations when a public official fixes a profitable deal for a firm he works for or owns stock in it. Public officials are obliged to deliver a report on their personal ownership and income 15 days after coming in office, for themselves, a spouse and children for purposes of preventing this type of corruption. Public officials must deliver these reports each year, and incomes gained during their time in office that have not been reported are considered illegal.

It is usual to distinguish corruption as contracting, political, spontaneous, judicial and general; as well s centralized and decentralized corruption.

Contracting corruption (corruption in public service) means concluding harmful contracts, assigning concessions, contingents and similar and taking provisions or other types of personal gain.

Political corruption has different forms, from creating black funds for financing political parties, to conscious implementation laws or acts. Political corruption is present in all the political systems, modern or ancient, regardless their class character and political shape and will certainly exist and endanger social prosperity and future regardless the fact that its existence is denied by individuals and political parties at the top of power.

Spontaneous corruption assumes all the types of spontaneous corrupting of public officials or responsible individuals with an aim to avoid their obligations defined by law, without a previous plan and a special announcement. These cases of corruption are characteristic for bribing customs officials, traffic police, financial police, inspection and other officials.

Corruption in administration of justice assumes all the forms of illegal behaviour of public administrators which have a consequence of breaking the rule of justice, equality under the law etc.

General corruption assumes all the other forms of corrupting official or responsible individuals in education, health, sport, etc.

Centralized corruption - appears only at the top of a state government for purposes of achieving personal gain and enlarging fortune (for example: taking percentage for enabling profitable contracts), so the state ruling circles become generators of this phenomenon, while decentralize corruption is committed by public administrators for their own gain when the state is not inclined to their wrongdoing, and it is mostly present in democratic societies. (Ivanovic, 2013)

Pantoflage is moving an administrative official from public to private sector, his employment or business cooperation is connected with economic subjects or international organizations whose business is connected to the job he previously did.

Pantoflage and cummulation of functions are not corrution, but by Law against corruption they are put among criminal acts. The question is why? Pantoflage carries a high risk of corruption because a pubic official is employed in a private firm and does the same job as he does at his public function. Cummulation of functions is a question of how a public official can do more functions at the same time and do all of them well and honestly. We come to a conclusion that pantoflage and function cummulation are not pure corruption but a hidden one. Serbian public is familiar with cases of public officials holding even 4 public functions which are all well paid and their day lasts for 48 hours.

Pantouflage is known in anglosaxon world as a "system of rotating doors" and during the recent years it has been identified as an area with extereme risk of corruption. We introduced it as a term by Law on corruption in 2010. By Law, it is called "Abbolishment of employment or business cooperation after performing a public function". Pantoflage is when a public official aafter his public function has been finished goes to a firm which has business in an area he dealt with or he organized by his decisions. Law on fighting against corruption orders that a public officer whose function finished can not be employed or cooperate with an individual, business owner or an 
international organization which does activity in connection the official performed unless he receives agreement from the Agency. The Agency must decide upon a request within 15 days of application. Prohibition does not reffer to a public official elected directly by the citizens - committee members, representatives, president. (ANEM, 2014)

Function cummulation endangers responsible execution of power. Conflict of inerest while cummulating functions does not mean basic conflict of interest - conflict of public and private interest. When we talk about conflict of interest while cummulating functions it refers to possibility to responsibly and fairly perfrm to demanding functions as functions of committee members, and Mayers. One more type of inerest conflict while cummulating functions is "collision" of oversight or controlling function with a function that is to be controlled. Struggle against function cummulation has been active ever since Republic board for solving interest conflict was established, when law enabled two functions at most. The Agency initiated changes in 2013 which enable one function only, and exceptions that are now a rule were diminished to only a situation when the Law allows an official to be obliged by some other function to perform both of them (for example - a Minister of finance is required to be a member of The Governing Board of the Fund for Development). More than 10,000 legal proceedings were submitted in 2009 for double functions. By June, 2014, Administrative Board allowed 14 emissaries to an additional job. In a large number of cases they do not need an approval from the board or Agency against corruption for some additional engagement, because state officials by law can have double functions if they do not cause a conflict of interest. Until October, 2014. more than 200 resignations to double functions were submitted.

A Present - "money, a thing, a right or a favour performed without a proper reward and any other gain given to an official or a connected person to a public function". The Law recognizes two categories "protocol gift" is a gift given by a foreign state, her organ or organization, international organization or an individual which was received during an official visit or a similar occasion and "an appropriate present" which is in practice the same as protocol but the giver is not a foreign state or its organ. An official is not allowed to receive a gift connected to performing a public function, except from protocol or appropriate gift, and not even then if it is money or valuable papers.

The official must submit the present to the authorized organ for dealing with public property, unless the value of the present is less than $5 \%$ of an average monthly pay without taxes deducted in the Republic of Serbia, or around $18 €$. The same goes for appropriate present - an official cannot keep an appropriate present if its value exceeds $5 \%$ of average monthly income - which means appropriate presents during the calendar year when total value exceeds one average monthly pay (around 360 Euros). Research conducted in 2012 showed that every fifth citizen considers giving presents to an official, so that he would do something that is actually his job was not a sin. Completing obligations through connections or using acquaintances is not corruption for $19 \%$ of people. (D.M.S, 2012)

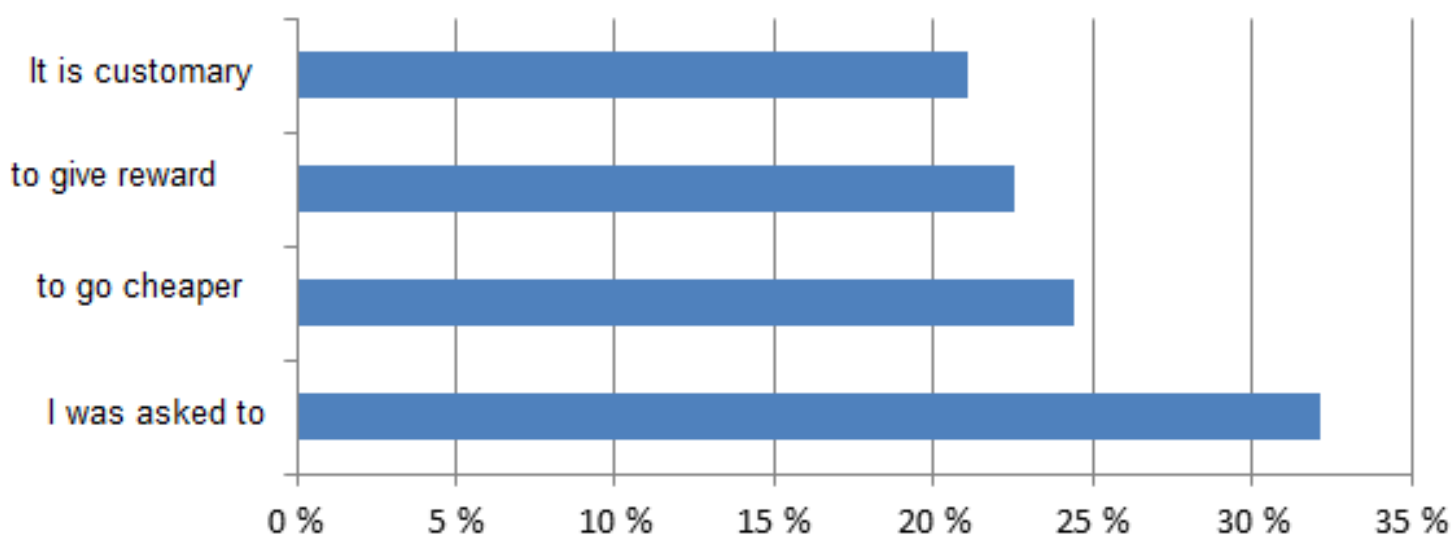

Fig. 1 Why did you give bribe? 


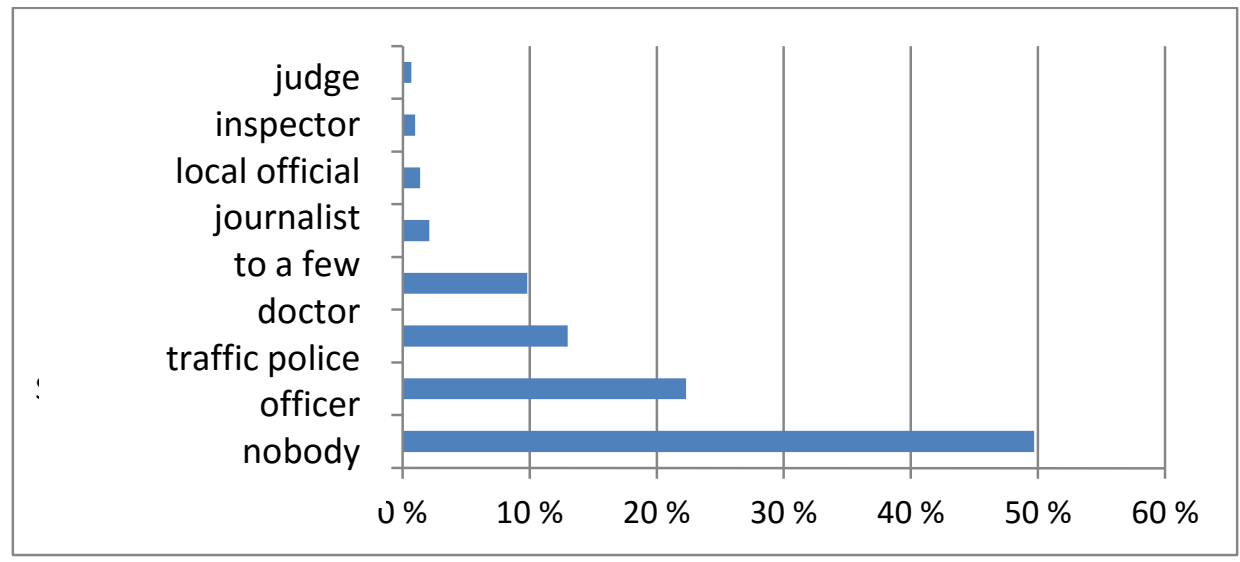

Fig. 2 Who did you give bribe to?

Site 021.rs conducted a research to why (fig. 1) and to whom (fig. 2) is bribe mostly given.

The questioners were answered by 788 visitors. (021, 2014A) The question "Who did you give bribe to?" was answered by 2640 visitors. (021, 2014B)

\section{CORRUPTION IN 2012-13.}

It has already been pointed that by available research, citizens gave 168 Euros bribe in December, last year, which is more than in Jun, 2012. Citizens think that corruption is most present in healthcare, judicial system and police, while "politicians and political parties go out of all the categories" as the research show. When questioned whether things in Serbia go to a right or wrong direction, $45 \%$ of the questioned chose wrong in December 2012,while in Jun, last year more than $70 \%$ of the questioned had that attitude, while $32 \%$ answered that Serbia is moving into a right direction, while in Jun, less than double questioned people had that attitude .

Citizens mostly bribed doctors, $25 \%$ of them, $19 \%$ bribed policemen, administrative officials and teachers $9 \%$ each, judges and prosecutors $5 \%$ each. Almost three quarters of citizens, $72 \%$, think that political parties are most corrupted, then healthcare $69 \%$, judicial system $64 \%$, prosecutors $62 \%$ and lowers $60 \%$.

The largest number of citizens $49 \%$ considers that the police are the central figure in fight against corruption, $41 \%$ sees the Government in that role, and $37 \%$ judicial system and $26 \%$ think that the Agency against corruption is the leader in the fight. Almost $4 / 5$ or $79 \%$ think that prison, or strict punishment measures are the best means in fight against corruption. $69 \%$ think that it is necessary to improve legal measures, while $61 \%$ pinpointed the necessity of strengthening state control over public administration.

\section{SITUATION IN SERBIA AND SURROUNDING COUNTRIES}

Serbia regressed in annual list of Transparency International and is now in $86^{\text {th }}$ place, with corruption index (CPI) 3.3 as we were informed by organization Transparency Serbia on 01.12.2012. In the annual report of Transparency it is stated that there is a decrease of score of corruption perception index from 3.5 in the last two years to 3.3 in 2011. The President of Transparency Serbia, Vladimir Goati, stated that the reasons for corruption in Serbia are slow reform of judicial system and weakening of institutioions, and called political parties generator for corruption. The list is marked from 1 to 10 , where the best mark goes to New Zeeland 9.5, and the worst, 1, goes to North Korea and Somalia. During 2010, Serbia shared a place between $78^{\text {th }}$ and $84^{\text {th }}$ with China, Greece, Columbia, Lesotho, Peru and Thailand, while in 2009 with the same index it was alone in the $83^{\text {rd }}$ place.

Of all the ex-YU countries the best place holds Slovenia with a score of 5.9 , in the $35^{\text {th }}$ place, Croatia and Montenegro share $66^{\text {th }}$ place, Macedonia is in the $69^{\text {th }}$ place while $\mathrm{BIH}$ is worse than Serbia and with an index 3.2 occupies $91^{\text {st }}$ place. Kosovo is ranked separately and is in the $112^{\text {th }}$ place with an index of 2.9. Albania is also worse than Serbia with 3.1, while Bulgaria has the 
same index as Serbia, concerning the countries in the region. (Beta, 2011)

Considering corruption in society our country is in the $83^{\text {rd }}$ place out of 180 countries where "Transparency International" conducted research on the topic. A conference in the palace "Serbia" was held for the World's day of fight against corruption, where a research of the TNS Media Galluš Agency was presented. The research was conducted on around 1000 citizens of Serbia. Disastrous statistics look like this:

- $15 \%$ said that they paid bribe to mostly doctors, policemen and state administrators in the last three months.

- $78 \%$ of the question citizens see the healthcare system as corrupted.

- $76 \%$ think that corruption exists in political parties.

- Judicial system or judges are seen as corrupted by $70 \%$ of the questioned.

- $\quad 72 \%$ of questioned people see the customs in the third place for the degree of corruption.

- Military (23\%) and religion (25\%) are seen as the least corrupted.

- $62 \%$ of questioned citizens see the parliament as corrupted institution.

- $61 \%$ think the Government is corrupted.

- $82 \%$ thinks that corruption influences their personal lives.

- $91 \%$ thinks that corruption is present in political life.

- $88 \%$ answered that corruption is present in business.

- $88 \%$ of the questioned thinks that corruption is a regular practice.

- $60 \%$ of the questioned expect corruption in certain degree.

- $65 \%$ of the questioned do not accept corruption.

- $41 \%$ of the citizens think that the level of corruption has grown in the last year.

- $18 \%$ expects the level of corruption to decrease in the next year.

- $\quad 1 / 4$ of the citizens in Serbia would be willing to give bribe if asked.

- Corruption is the third problem in Serbia, after unemployment and poverty, answered the questioned citizens. (Gluvakovic, 2009)

\section{CORRUPTION IN 2014}

Agency for fight against corruption has brought 12 criminal charges for existing doubt that an official hasn't reported his property to the Agency or has given false information about it for purposes of hiding property.

From 01.01.2014 to 01.10.2014 the Agency started 453 procedures, while performing activities in its jurisdiction referring to register of officials, register of property and income, and list on procurement procedures, to establish whether breaking regulations of the Law appeared.

Out of those cases:

- 27 for the officials being late to transfer manager rights during the period defined by Law.

- 4 - for being late to inform the Agency on public procurement procedures

- 3 for receiving presents not according to the Law.

- 210 for being late in delivering report on property and income after starting a job in office.

- 195 for being late to deliver reports on property and income after finishing the job in office.

- 12 for being late to deliver reports on property and income after significant changes.

The Agency for fighting against corruption pronounced 389 warning measures, as follows:

- 14 for the officials being late to transfer manager rights during the period defined by Law.

- 2 for receiving presents not according to the Law.

- 185 for being late in delivering report on property and income after starting a job in office.

- 170 for being late to deliver reports on property and income after finishing the job in office.

- 12 for being late to deliver reports on property and income after significant changes.

Totally 11 measures of publicly announced decisions on braking Law were pronounced as follows: 
- 6 for not transferring manager rights during a public function were performed in a period of time defined by Law.
- 48 for being late in delivering report on property and income after starting a job in office.

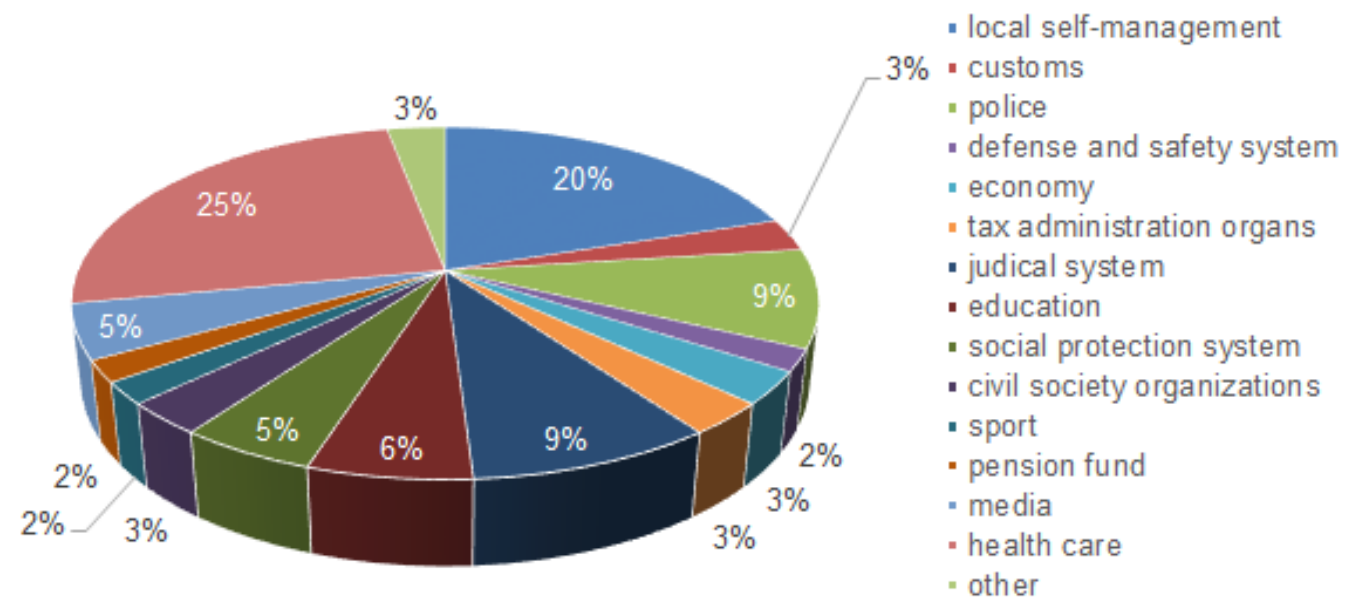

Fig. 3 Distribution of corruption by spheres

- 2 for being late to inform the Agency on participating and public procurement procedures.

- 1 for being late in delivering report on property and income after starting a job in office.

- 2 for being late to deliver reports on property and income after finishing the job in office.

Total 114 requests to start misdemeanor procedures were submitted to Belgrade Misdemeanor court as follows:

- 4 for being late to transfer manager rights.

- 1 for being late to inform the Agency on participating public procurement procedures.

- 1 for receiving presents not according to the Law.

- 6 an organ or a responsible person in that organ was late to inform the Agency on beginning /end of public function of an official in that organ.
- 52 for being late to deliver reports on property and income after finishing the job in office.

- 2 for being late to deliver reports on property and income after significant changes.

12 reports of justifiable doubt that criminal offences were committed for which one should be prosecuted in line of duty were submitted to prosecutor's office and which were not predicted by Law of the Agency. 15 reports were submitted to authorized organs for justifiable doubt that criminal offences out of their jurisdiction were committed and as follows:

11 to money laundry prevention office, 4 to tax administration. (Vesti, 2014)

\section{WHERE THE CORRUPTION IS SITUATED MOSTLY?}

Research has shown that corruption exists mostly in the spheres shown on fig. 3. (Anketa, 2014)

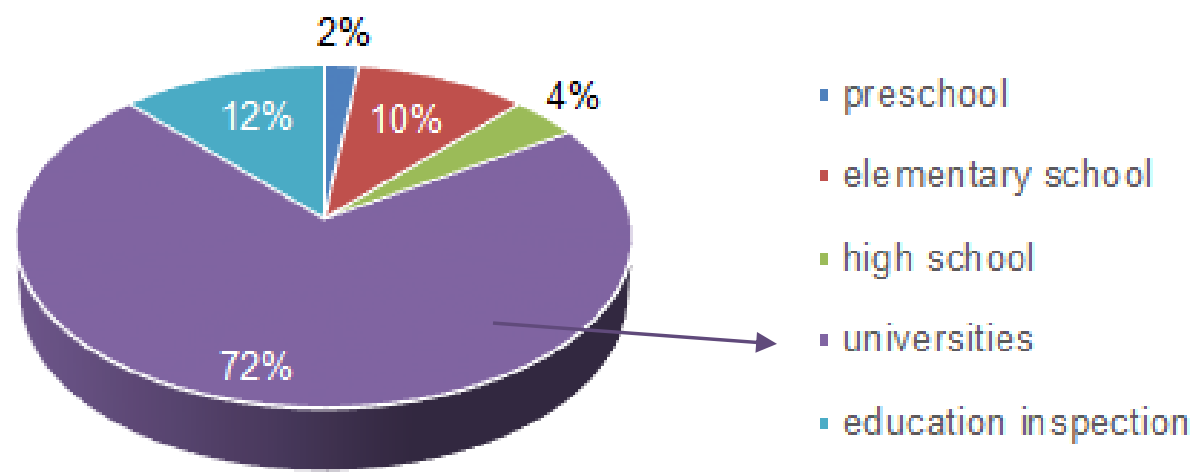

Fig. 4 Areas of education mostly infected by corruption. (Anketa, 2014) 


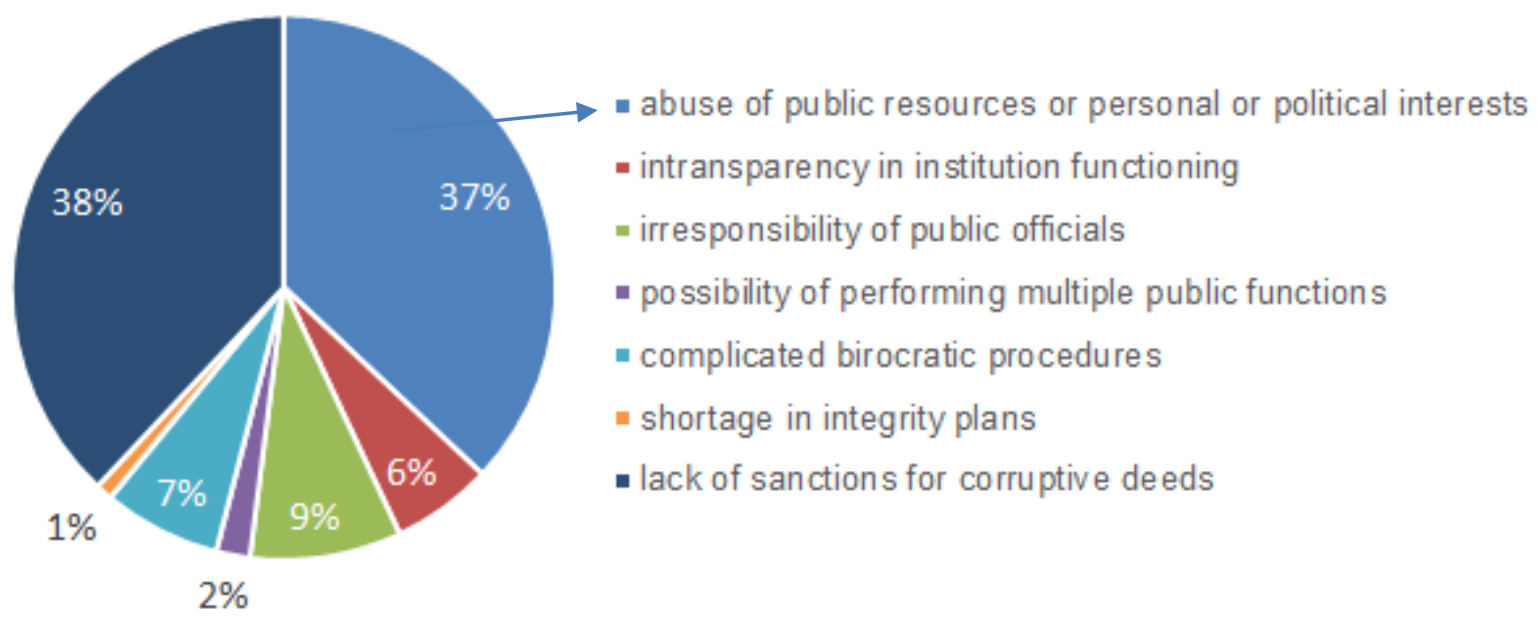

Fig. 5 In public sector corruption is encouraged by... (Anketa, 2014)

From 2007 to 2009 the prosecutor's office received 11.823 denunciations, which mostly came from the police $(45 \%)$, after that follow denunciations from citizens, whether directly harmed or others. The largest number of denunciations was qualified as "abuse of power" $(62 \%)$, even though this qualification covers a large number of criminal offences some of which are not corruption cases. The other type of criminal denunciations refers to "breaking law by judges, public prosecutor or his deputy" $(16 \%)$ and criminal offence of embezzlement $(11 \%)$. A large number of citizens $(39 \%)$ who reported on corruption in judicial system did that because they thought that judges or prosecutors broke the Law. Cases of giving or receiving bribe were rarely subject of criminal denunciation (2.5\%), and were least submitted by the citizens (only $1.5 \%$ ). (Duyne, Stocco, \& Dimitrijevic, 2011, p. 11)

\section{CONCLUSION}

Corruption in our country is nothing new. We are already used to it, so we sometimes do not notice it. Nevertheless, with education growth of the broadest layers of population and their emancipation, a need appears for all the relationships among the factors in our social system to be transparent. Corruptive relationships do not appear by themselves out of nothing. They are the product of a system. Two sides are needed for corruption, one that offers bribe and the other that receives it, and looking from a side somebody should look at it benevolently. All the parts of state system should be coordinated to be able to decrease corruption. Citizens mostly bribed doctors in 2012, around $25 \%$ of them, police officers $19 \%$, public officials and teachers $9 \%$, and public prosecutors and judges bribed $5 \%$ of citizens each. Almost $3 / 4$ of citizens, $72 \%$ considers political parties to be most corrupted, followed by healthcare $69 \%$, judicial system $64 \%$, prosecutors $62 \%$ and lowers $60 \%$.

Higher quality system of giving awards, or evaluating work, is a basic premise of prevention which will most directly cut off or start corruption. A worker, official or a manager with decent wages will not easily decide to lose the privilege of regular monthly income for some money or a favour. On the other hand, low, irregular wages, which are mostly the case, open the door for corruption and this is why there is a feeling that everything is for sale. This is confirmed by results of numerous researches.

Sanctions for corruption are also a significant element preventing people to do such deeds. Transparent and strict sanction politics would lead to punishing all the similar cases in similar way, and bringing new criminal laws and making regulations stricter would undoubtedly have prevention effect or general prevention. From 2007-2009 prosecutor's office received 11,823 criminal denunciations, done mostly by the police and then citizens. The largest number of denunciations was qualified as "power abuse", even though this qualification covers a number of criminal offences that are not all corruption. 


\section{WORKS CITED}

021. (2014A, Dec 06). Zasto ste dali mito. Retrieved from 021.rs: http://www.021.rs/?option=com_poll\&id=191:zato-ste-dali-mito

021. (2014B, Dec 06). Kome ste dali mito? Retrieved from 021.rs: http://www.021.rs/?option=com_poll\&id=189:kome-ste-dali-mito

ANEM. (2014, Mar 24). Recnik korupcije. Belgrade, Serbia: ANEM. Retrieved from http://www.anem.rs/sr/aktivnostiAnema/produkcija/llustrovanirecnikkorupcije/story/15994/Po\% C4\%8Delo+emitovanje+ANEM-

ovog+serijala+\%E2\%80\%9Ellustrovani+re\%C4\%8Dnik+korupcije\%E2\%80\%9C+.html

Anketa. (2014, Dec 01). Retrieved from Prijavikorupciju: http://prijavikorupciju.rs/anketa/rezultati/9\#sthash.BuEUiZR2.dpuf

Beta. (2011, Dec 01). Porast korupcije u Srbiji. Retrieved from EurActiv: http://www.euractiv.rs/eu-izapadni-balkan/3194-porast-korupcije-u-srbiji-

Bible. (1963). Exodus 23 - Sundry Laws 8. In B. Hub, New American standard bible. Retrieved from http://biblehub.com/nasb/exodus/23.htm

Boskovic, M. (1999). Kriminoloski leksikon. Novi Sad: Matica Srpska and University of Novi Sad.

D.M.S. (2012, Nov 23). Mediji o korupciji - Mito nude preko veze. Retrieved from Vlada Republike Srbije - Savet za borbu protiv korupcije: http://www.antikorupcija-savet.gov.rs/dogadjaji/cid10422164/mito-nude-preko-veze

Dušan, S. E. (1349). Dušan's Code. Retrieved from Overa: http://www.overa.rs/dusanov-zakonik-2.html

Duyne, P. C., Stocco, E., \& Dimitrijevic, J. (2011). Politika borbe protiv korupcije u Srbiji. Beograd: Tilburg University and Viktimolosko drustvo Srbije.

Gluvakovic, T. (2009, Dec 10). Sumorna statistika. Retrieved from Vreme: http://www.vreme.com/cms/view.php?id=902060

Ivanovic, J. (2013). The manifestation and prevention of corruption in Serbia and neighboring countries. Proceedings of the 3rd International Conference 'Law, Economy and Management in Modern Ambiance'. 3, pp. 1300-1307. Belgrade, Serbia: LEMiMA.

Ivanović, J. (2013). Appearing and preventing Corruption in Serbia and Surroundings. Belgrade, Serbia: FORKUP, LEMIMA.

Klitgaard, R. (2008, Jan 29). A Holistic Approach to the Fight against Corruption. Retrieved from Claremont graduate university: http://www.cgu.edu/PDFFiles/Presidents\%200ffice/Holistic_Approach_1-08.pdf

Koprivica, V. (2013, Dec 06). Korupcija kroz vjekove (I): Mito za asirsku princezu. Retrieved from Monitor online:

http://www.monitor.co.me/index.php?option=com_content\&view=article\&id=4821:korupcijakroz-vjekove-i-mito-za-asirsku-princezu\&catid $=3317$ : broj-1206\&ltemid $=4577$

Milosevic, M. (2012). Krivicno pravo. Novi Sad, Serbia.

Selosa, G. H. (2010, Dec 09). A "Formula" to Descrie Social Accountability. Retrieved from ANSA VOICES: http://voices.ansa-eap.net/2010/12/formula-to-describe-social.html

Tanci, V. (n.d.). O korupciji - Definicije. Retrieved Sep 01, 2015, from Vlada Republike Srbije - Savet za borbu protiv korupcije: http://www.antikorupcija-savet.gov.rs/content/cid1006/definicije

Vesti. (2014, Dec 01). Retrieved from Prijavi korupciju: http://prijavikorupciju.rs/vesti 
Vujanic, M., \& at al. (2011). Rečnik srpskog jezika. Novi Sad, Serbia: Matica Srpska.

Received for publication: $\quad 27.11 .2014$

Revision received: $\quad 08.09 .2015$

Accepted for publication: $\quad 20.10 .2015$

\section{How to cite this article?}

Style - APA Sixth Edition:

Ivanovic, J., \& Teslic, M. (2016, January 15). Corruption in Serbia and in surroundings. (Z. Cekerevac, Ed.) MEST Journal, 4(1), 19-30. doi:10.12709/mest.04.04.01.03

Style - Chicago Sixteenth Edition:

Ivanovic, Jelena, and Marko Teslic. 2016. "Corruption in Serbia and in surroundings." Edited by Zoran Cekerevac. MEST Journal (MESTE) 4 (1): 19-30. doi:10.12709/mest.04.04.01.03.

Style - GOST Name Sort:

Ivanovic Jelena and Teslic Marko Corruption in Serbia and in surroundings [Journal] // MEST Journal / ed. Cekerevac Zoran. - Belgrade-Toronto : MESTE, January 15, 2016. - 1 : Vol. 4. - pp. 19-30.

Style - Harvard Anglia:

Ivanovic, J. \& Teslic, M., 2016. Corruption in Serbia and in surroundings. MEST Journal, 15 January, $4(1)$, pp. 19-30.

Style - ISO 690 Numerical Reference:

Corruption in Serbia and in surroundings. Ivanovic, Jelena and Teslic, Marko. [ed.] Zoran Cekerevac. 1, Belgrade-Toronto : MESTE, January 15, 2016, MEST Journal, Vol. 4, pp. 19-30. 